\title{
GAMMA RAY SPECTROMETRY AND LANDSAT TM SATELLITE IMAGES APPLIED TO THE STUDY OF THE SEDIMENTARY PHOSPHATES OF IRECE BAHIA (BRAZIL)
}

\section{Miguel ÂNGELO MANE ${ }^{1 *}$, DANIEl JEAN RogER NORDEMANN ${ }^{2}$ AND ADOLPHO JosÉ MELFi ${ }^{3}$}

1 Universidade do Estado do Rio de Janeiro - UERJ, Faculdade de Geologia, Departamento de Geologia Aplicada. Av. São Francisco Xavier, 524, Maracanã. 20550-900 Rio de Janeiro, RJ, Brazil. migangel@uerj.br

2 Instituto Nacional de Pesquisas Espaciais, Av. dos Astronautas, 1758. Jardim da Granja, São José dos Campos, São Paulo - SP, 12227-010 Brazil. daniel.nordemann@hotmail.com

3 Instituto de Energia e Ambiente, Universidade do Estado de São Paulo - USP. Av. Prof. Luciano Gualberto, 1289 Butantã, São Paulo - SP, 05508-010 Brazil. ajmelfi@usp.br

*Corresponding author, migangel@uerj.br

Received on 17 September 2017

Received in revised form on 26 October 2017

Accepted on 28 October 2017

Editor: Maria Virginia Alves Martins, Universidade do Estado do Rio de Janeiro, Brazil

\section{SCREENED BY}

iThenticate

Citation:

Mane, M.A., Nordemann, D.J.R., Melfi, A.J., 2017. Gamma Ray spectrometry and Landsat Tm satellite images applied to the study of the sedimentary phosphates of Irecê Bahia (Brazil). Journal of Sedimentary Environments, 2 (3): 167-181.

\section{Abstract}

This work aims to study phosphate exploration areas through the application of gamma-ray spectrometry and remote sensing, using satellite images of Landsat Thematic Mapper (TM) sensor. The selected zone for this study is located in the Irecê region (Bahia State, Brazil). Geologically it represents an environment with phosphate deposits, associated to the Precambrian limestone of the Una Group. The presence of this mineralization was discovered and prospected by the "Companhia de Pesquisa de Recursos Minerais" (CPRM; Company of Research of Mineral Resources) and the "Companhia Baiana de Pesquisa Mineral" (CBPM; Bahia State Company of Mineral Research). This is a relevant issue due to the importance of

\section{Introduction}

Natural radioactivity has been used in mineral exploration, due to the characteristics of some radioisotopes (unstable nuclei), whose nuclear properties allow in their decay to transform into isotopes of other elements, with emission of particles and energy release (De Meijer et al., this mineral resource to Brazil economy. The satellite images and gamma ray maps analyzed in this work: evidence that ${ }^{232} \mathrm{Th}$ anomalies have the best relationship with the data obtained by the CBPM through geological mapping; allowed to identify two new other potential mineralization areas in Irecê region; are useful for mapping phosphates concentrations and to identify new potential areas of phosphate mineralization.

Keywords: Geophysical analysis. Mineral resource. Phosphates. Natural radioactivity. Uranium, thorium and potassium isotopes.

1997). These elements provide information on the environment in which they are measured by their concentrations, radioactivity emissions, and / or associated elements in the study of important mineralizations. An interesting case is the apatite whose mineralization can be 
localized by the detection of gamma radiation due to its frequent association with the radioactive elements, such as thorium and uranium (Shalaby et al, 2010).

As a tool for obtain and analyzing multispectral images in the field of visible and adjacent radiation, remote sensing allows to observe characteristics that, according to the literature, help to distinguish the most diverse materials exposed at the terrestrial surface (McInnis and Akhavi, 1986). The simultaneous use of satellite images with gamma radiation measurements has the advantage of being able to relate the presence or absence of mineralization with observed surface features in the visible or adjacent wavelength ranges (Lillesand et al., 2008). The comparison of results obtained by both methods is quite interesting since they allow to acquire complementary information. They are based on measured electromagnetic radiation but with very different wavelengths. The gamma radiation, generated from nuclear de-excitation processes, has much greater energy than the visible radiation (Eisenbud et al., 1977), but when combined they can improve the surficial information and can be very useful in geology.

The physicochemical mechanisms that occur naturally in the terrestrial crust and influence the processes of rock weathering and soil formation, can affect the distribution of the potassium $(\mathrm{K})$, thorium (Th) and mainly uranium (U) elements (Dickson et al., 1997).

The phosphate deposits, provided by both sedimentary and igneous rocks, are mostly composed almost exclusively by apatite. Belonging to the family of phosphates, they have the general formula of equation 1 (Pecora, 1967):

$$
\mathrm{Me}_{10}\left(\mathrm{XO}_{4}\right)_{6} \mathrm{Y}_{2}
$$

Where:

$$
\begin{aligned}
& \mathrm{Me}=\mathrm{Ca}, \mathrm{Pb}, \mathrm{Zn}, \mathrm{Sr}, \mathrm{Na}, \mathrm{Be}, \mathrm{Cd}, \mathrm{TR} \\
& \mathrm{X}=\mathrm{P}, \mathrm{As}, \mathrm{V}, \mathrm{S}, \mathrm{C}, \mathrm{Si} \\
& \mathrm{Y}=\mathrm{F}, \mathrm{OH}, \mathrm{Cl}, \mathrm{Br}
\end{aligned}
$$

Substitutions are common and important, and it is practically impossible to obtain pure poles of the major constituents of the family such as francolite (fluorcarbonate apatite), dahlite (hydrocarbonate apatite) and hydroxyapatite or chloroapatite (Reginer et al., 1994).

\subsection{The main goals}

This work aims to study the exploration areas for phosphates in Irecê region (Bahia State, Brazil) through the application of gamma-ray spectrometry and remote sensing using satellite images. Surface geophysical studies should be the starting point to improve the knowledge on the phosphate deposits. They have several advantages such as low cost and fast data acquisition that allow the identification and geometric definition of such deposits. These geophysical methods contribute to the increase of our knowledge on the genesis conditions and evolution of phosphate deposits. They help to define guidelines for prospecting sedimentary phosphates and to improve the benefits of these deposits exploration.

\section{Study area}

The study area is located in the region of Irecê Bahia (Brazil) between the latitudes $11^{\circ} 00^{\prime} \mathrm{S}$ and $11^{\circ} 30^{\prime} \mathrm{S}$ and longitudes $41^{\circ} 30^{\prime} \mathrm{W}$ and $42^{\circ} 00^{\prime} \mathrm{W}$ (Fig.s 1-3). The Irecê city is located at $489 \mathrm{~km}$ from Salvador city, in the physiographic zone called Chapada Diamantina, covering the north-central region of the Bahia State (Brazil). The morphological unit carved on limestone rocks is represented by a peneplanted plateau, with altitude of about $750 \mathrm{~m}$ and is marked by karstic features. The large hydrographic basin includes several rivers such as: São Francisco (Fig. 1), Verde, Jacaré, Salitre, Una and Utinga, which allow a good distribution of water to the region.

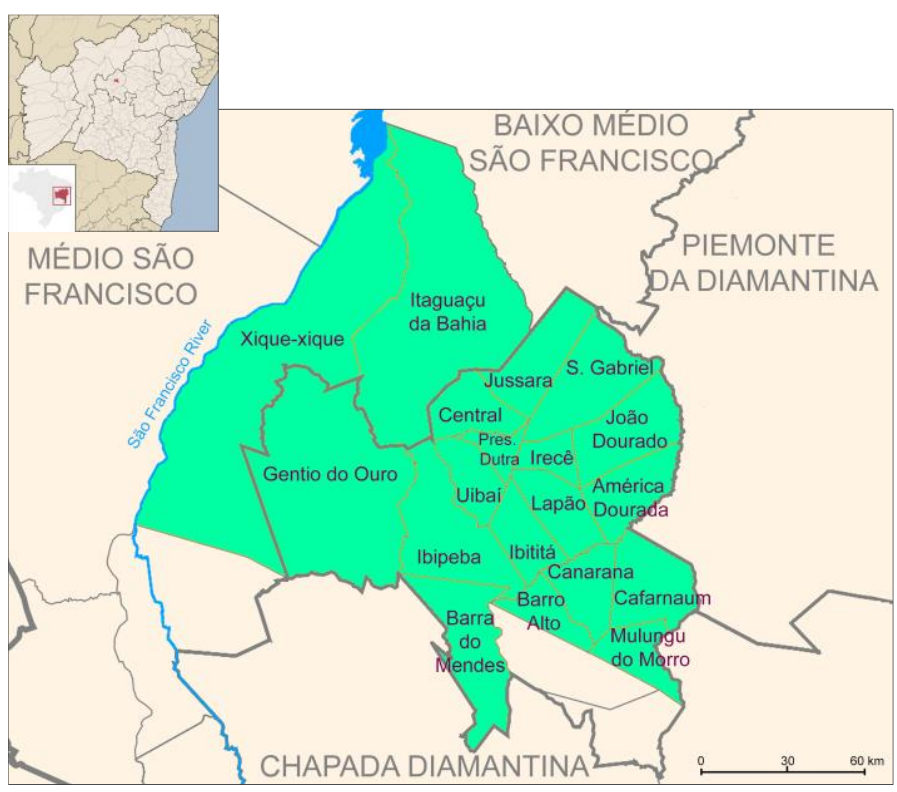

Fig. 1. Location map of the study area (from http://www.salobro.com/2011/08/regiao-metropolitana-de-irece-um.html)

\subsection{Geological Context}

The area is located in the structural unit known as the Irecê Basin (Misi, 1979). It is located in the central portion of the São Francisco Craton (Fig. 2, A), where the carbonate sequence of Una Group, chrono correlated with the sediments of the Salitre Formation, was deposited (Alkmim, 2004). Neo-Proterozoic sedimentary rocks, affected by the 
Brazilian Orogeny, cover the region $(600 \mathrm{Ma} \pm 100 \mathrm{Ma})$ (Dalton de Souza et al., 2003).

The deposits of the Una and Bambuí groups (São Francisco Super Group; Fig. 2) form large extensions that cover approximately half of São Francisco Craton (Bomfim et al., 1985; Kuchenbecker et al., 2011). The Una Group cover sequences settle discordantly over the crystalline basement and rocks of the Espinhaço Group and the Chapada Diamantina Group (Bomfim et al., 1985). According to Mascarenhas (1984), the lithotypes of the area are composed of calcarenites of varied granulation and stromatholytic levels (Fig. 3).

Bomfim et al. (1985) performed a systematic mapping of the Irecê Basin, where the sedimentary facies and associated depositional environments were identified. These studies allowed identifying three depositional cycles: an initial, a transgressive and an intermediate regressive. These authors showed that the carbonaceous sequence is varied, being common the intercalations of dolomites and clay.

The geological studies carried out by several authors in the Irecê region (Srivastava, 1986; Neves et al., 1985; Monteiro, 1988, 1989, 1990) allowed to know that the sedimentary deposits with $\mathrm{P}_{2} \mathrm{O}_{5}$ contents up to $39 \%$ are closely associated with colonies of stromatolites with occurrences in regressive sedimentary sequences. The Irecê sedimentary deposits are not yet fully characterized both as regarding the phosphate reserve and as the definition of its geometry. However, the mentioned works allowed to verify that the Irecê deposits are similar to those of India and represent one of the largest deposits in the World having an estimated reserve of phosphates of about 50 million of tons.

\section{Material and methods}

This work is based on a geophysical study carried out in the region of Irecê (Fig. 1). The region was previously studied by CPRM (1974) and CBPM (1993). These institutions previously mapped the potential for phosphate and sulfide occurrence in the region between Irecê and Lapão based on geological mapping (Fig. 3). Considering the previously mapped regions, the present study considers obtained airborne and ground geophysical data in the area between latitudes $-11^{\circ} 27^{\prime}$ and $-11^{\circ} 42^{\prime}$ and longitudes $-11^{\circ} 75^{\prime}$ to $-41^{\circ} 90^{\prime}$ (Fig. 4).

\subsection{Airborne Gamma ray spectrometry}

The gamma radiation produced by the natural radioactive isotopes on the Earth's surface is found in the geosphere and atmosphere, covering a range of 0.2 to 3.0
$\mathrm{MeV}$, where it is also provided by cosmic radiation, in the form of background noise. The mineralogical radioactivity is caused by the inclusion of naturally radioactive elements in their crystallochemistry composition. The degree of radioactivity is dependent on the concentrations and on the isotopes types present in the mineralogical composition (Ferreira, et al., 1992). Most part of the minerals that contain potassium $(\mathrm{K})$, uranium $(\mathrm{U})$, and thorium (Th) are radioactive. Rock phosphate ore processing and disposal of phosphogypsum contribute to enhanced levels of natural radionuclides in the environment (Sahu et al., 2014).

According to the UNSCEAR (2000) report, the world average value of activity concentration for ${ }^{238} \mathrm{U}$ is $35 \mathrm{~Bq} / \mathrm{kg}$, for ${ }^{232} \mathrm{Th}$ is $35 \mathrm{~Bq} / \mathrm{kg}$ and for ${ }^{40} \mathrm{~K}$ is $370 \mathrm{~Bq} / \mathrm{kg}$. For airborne survey, the gamma ray counts average in the study area is, according to CBPM (1993), that presented in Table 1.

Tab. 1. Averages and estimated errors for the values of the aerial counts (altitude of the aircraft: $150 \mathrm{~m}$, speed: $220 \mathrm{~km} / \mathrm{h}$, duration of the gamma counts: $1 \mathrm{~s})$.

\begin{tabular}{|l|r|c|}
\hline \multirow{2}{*}{$\begin{array}{c}\text { Chanel } \\
\text { Elements }\end{array}$} & \multicolumn{2}{|c|}{ Counts with correction } \\
\cline { 2 - 3 } & Counts & Standard deviation \\
\hline Potassium & $16.6 \pm 3.1 \mathrm{cps}$ & $19 \%$ \\
\hline Uranium & $4.6 \pm 2.4 \mathrm{cps}$ & $53 \%$ \\
\hline Thorium & $11.8 \pm 1.7 \mathrm{cps}$ & $15 \%$ \\
\hline
\end{tabular}

In order to obtain the counts related to specific emissions of each radioactive element, it was necessary to make corrections that sought to subtract from the areas of the respective peaks the indirect contributions of the other nuclides by Compton Effect. These corrections were done through the following expressions:

$$
\begin{aligned}
& \mathrm{D}(\mathrm{U}) \text { cor }=\mathrm{D}(\mathrm{U})-\alpha \mathrm{D}(\mathrm{Th}) \\
& \mathrm{D}(\mathrm{K}) \text { cor }=\mathrm{D}(\mathrm{K})-\beta \mathrm{D}(\mathrm{Th})-\gamma \mathrm{D}(\mathrm{U}) \text { cor }
\end{aligned}
$$

Where $\alpha$ is the correction coefficient of uranium relative to thorium; $\beta$ is the correction of potassium relative to thorium and; $\gamma$ is the correction of potassium with respect to uranium (already corrected the Compton effect), with the following definitions:

$\mathrm{D}(\mathrm{U}) \mathrm{cor}=$ correction of the Compton effect (uranium)

$\mathrm{D}(\mathrm{K}) \mathrm{cor}=$ correction of Compton effect (potassium)

$\mathrm{D}(\mathrm{U})=$ correction of atmospheric noise (uranium)

$\mathrm{D}(\mathrm{K})=$ correction of atmospheric noise (potassium)

$\mathrm{D}(\mathrm{Th})=$ correction of atmospheric noise (thorium)

The total volume of the airborne detector crystals was 831 cubic inches (13.6 liters), where the absorption 
coefficients obtained were $\alpha=0.367 ; \beta=0.507$ and; $\gamma=$ 0.781 . The total attenuation coefficient of gamma radiation due to the absorption of this radiation in the air and between the ground and the detector on board of the aircraft is the sum of the coefficients due to Compton scattering, photoelectric effect and pair formation. For the gamma spectrometry, the Compton scattering is considered in the energy bands used, considering the negligible contribution of the photoelectric effect and the formation of pairs (Parks, 2015).

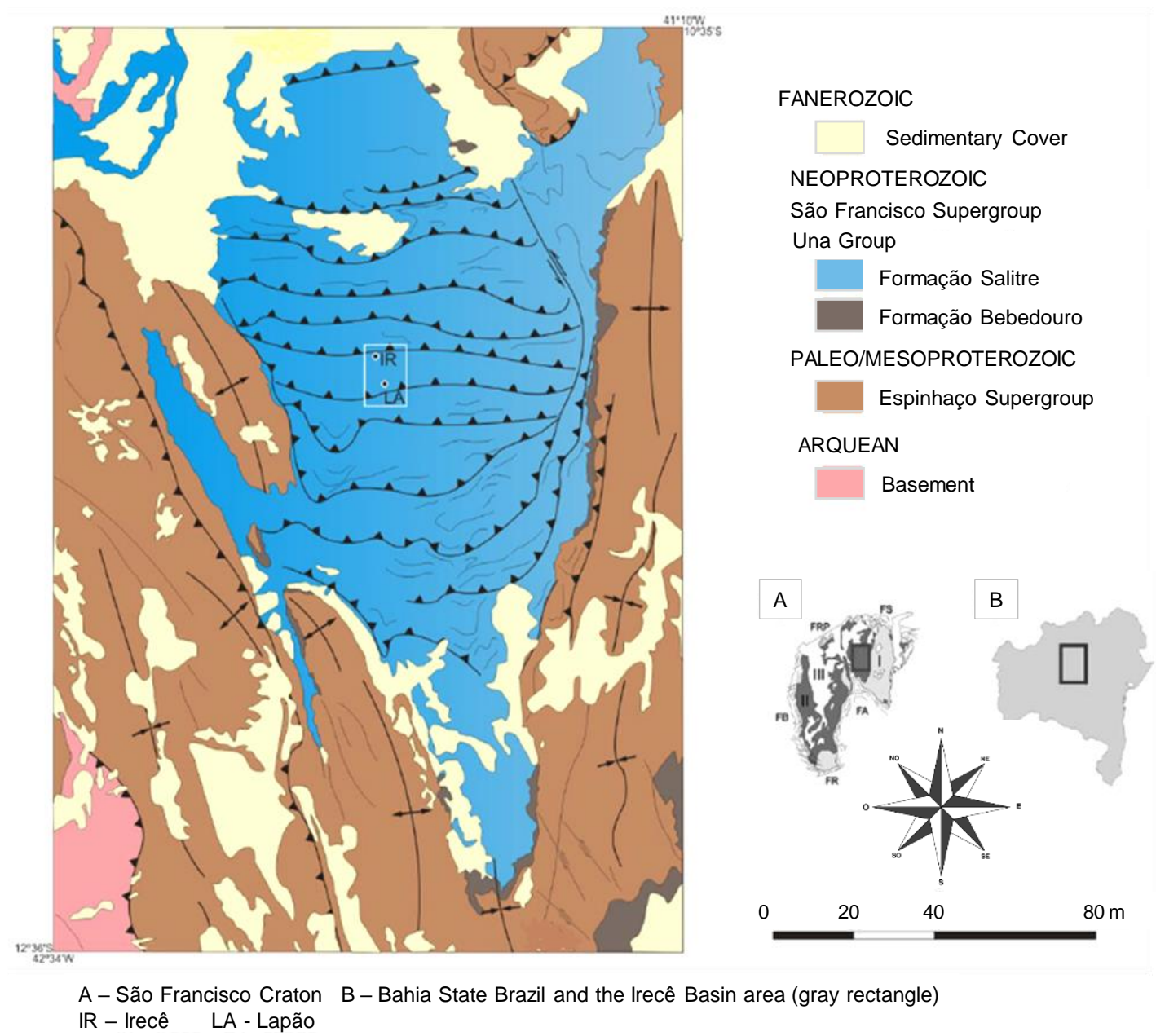

Fig. 2. Synthetic geological map and profile of the Irecê Basin region (modified from Alkmim, 2004). The white board marks the study area. IR - Irecê; LA - Lapão. (A) Location of the Irecê Basin region in relation to the São Francisco Craton. Map area in red. I - Basement (> $1.8 \mathrm{Ga}$ ); II - Neoproterozoic cratonic cover; III - Phanerozoic Coverage; FA - Araçuaí Range; FR - Ribeira Range; FB Brasília Band; FRP - Rio Preto and Pontal Creek; FS - Sergipana Band. (B) Location of the map area (red) in Bahia State.

The attenuation of the radiation levels with the increase of the height of flight established approximately between the heights of $50 \mathrm{~m}$ and $250 \mathrm{~m}$, obeys to an exponential function (Minty, 1988) of the equation (4):

$$
N=N_{0} e^{-\mu H}
$$

Where:

$\mathrm{N}=$ radiation measured in a channel at a height $\mathrm{H}$
$\mathrm{N}_{\mathrm{o}}$ = radiation measured at zero level, that is, above the rock or soil surfaces

$\mu=$ the atmospheric attenuation coefficient of the measured radiation in the channel.

Developing the equation in (4), it is obtained:

$$
\ln _{(\mathrm{N})}=-\mu \mathrm{H}+\ln \left(\mathrm{N}_{\circ}\right)
$$


Where: $\ln (\mathrm{N})$ e $\ln \left(\mathrm{N}_{\mathrm{o}}\right)$ are the values of the neperian logarithms of $\mathrm{N}$ and $\mathrm{N}_{\mathrm{o}}$. This equation being the line where $-\mu$ is the angular coefficient of the line and $\ln \left(N_{\circ}\right)$ is the independent term.

The mathematical functions 6 and 7 allow determining the parameters $\mu$ and $\ln \left(N_{\circ}\right)$ by the least squares method:

$$
\begin{aligned}
& \mu=\frac{\sum h \sum \ln (N)-n \sum(h \cdot \ln (N))}{n \cdot \sum h^{2}-\left(\sum h\right)^{2}} \\
& \ln \left(N_{0}\right)=\frac{\sum h^{2} \sum \ln (N)-\sum h \cdot \sum(h \cdot \ln (N))}{n \cdot \sum h^{2}-\left(\sum h\right)^{2}}
\end{aligned}
$$

Where $\mathrm{n}$ is the measured numerical value (CBPM, 1993).

The values of $\mu$ obtained for the aircraft were:

Potassium $(\mathrm{K})=0.0028537 / \mathrm{m}$

Uranium $(\mathrm{U})=0.0029583 / \mathrm{m}$

Thorium $(\mathrm{Th})=0.0054675 / \mathrm{m}$

Total Counts $(\mathrm{TC})=0.0003580 / \mathrm{m}$

Through the values of the absorption coefficient, the gamma radiation data were corrected for the same height, in the case $150 \mathrm{~m}$, allowing relating these values with the levels of radioactive elements in the surface of the ground, regardless of the height of flight of the aircraft.

The coefficients of atmospheric attenuation of gamma radiation in the energy bands of the channels used allowed correcting, point by point, for a height of $150 \mathrm{~m}$, the data measured by the following equation (8):

$$
D=D_{0} e^{\mu(H-150)}
$$

Where $\mathrm{D}$ is the corrected point value of the Compton scattering in the crystal, $\mu$ is the calculated attenuation coefficient for the channel; $\mathrm{H}$ is the height in relation to the soil on which the measurement was made, and $\mathrm{D}$ is the value of the content of the height-corrected channel.

\subsection{Ground gamma ray spectrometry}

Considering the layer of soil with uniformly distributed activity, this being quite extensive both laterally and in depth, more than $50 \%$ of the radiation intensity emitted by the soils comes from the upper layer, which is approximately $50 \mathrm{~cm}$ (Leipunskii et al., 1965).
Thus, when the distribution of activity is uniform in the thick layer of the absorber, the intensity of gamma radiation on the surface can be calculated by the equation (9):

$$
J=\alpha \frac{1}{2} g \lambda_{e f}\left(1-\frac{h}{l_{0}}\right)
$$

Where:

$l_{0}=\left(\mathrm{r}_{0}^{2}+\mathrm{h}^{2}\right)^{1 / 2}$

$\mathrm{h}=$ detector height

$1=$ distance from the detector to the largest radius aperture $\mathrm{r}$

$\mathrm{g}$ is the specific activity in $\mathrm{MeV} / \mathrm{seg} \cdot \mathrm{cm}^{3}$

$\alpha$ and $\lambda_{\text {ef }}$ are experimentally determined and tabulated coefficients for several materials.

The attenuation factor for the layer can be expressed by equation (10) below:

$$
K=\alpha e^{-x / \lambda_{e f}}
$$

Where $\mathrm{x}$, is the thickness of the radiant layer.

By equation (9), the intensity dependence on the center of the active and thick region of the absorber is determined, with an area of radius $r_{0}$. For a uniform absorber, only a fraction of the total radiation intensity of the measurement point comes from active soil regions for distances greater than 10.

For $\mathrm{h}=1 \mathrm{~m}$, regions of the absorber spaced more than $10 \mathrm{~m}$ from the measurement point may contribute only by $10 \%$ of the total radiation intensity. Those areas more than $20 \mathrm{~m}$ contribute less than $5 \%$. The detector height above ground ratio and the radius of the analyzed area at $90 \%$ can be obtained by equation (11):

$$
\mathrm{r}=10 \mathrm{~h}
$$

Ground measurements were made within $1 \mathrm{~m}$ of the soil. This procedure allowed analyzing an area of 10 meters of radius centered in the point of investigation, with contribution of $90 \%$ of radiation (Leipunskii et al., 1965).

\subsection{Instrument of ground measurements}

A Scintrex GAD6 portable spectrometer with GSP3 sensor of 0.12 liters of volume was used in this work, with 5 minutes integration per point of measurement. This equipment has good stability with the range of power windows established in: K (1380-1560 keV), U (1660-1900 $\mathrm{keV})$, Th (2580-2650 keV) and total account TC (800-2770 $\mathrm{keV}$ ). 


\subsection{Statistical Analysis}

The two-dimensional analysis of the distribution of measured values in any sample usually has a correlation coefficient $r$, which shows the reciprocal dependence of these values. According to Meyer (1984), two-dimensional random variables $(\mathrm{X}, \mathrm{Y})$ give rise to a random sample $\left(\mathrm{X}_{\mathrm{i}}, \mathrm{Y}_{\mathrm{i}}\right)$ to $\left(\mathrm{X}_{\mathrm{n}}, \mathrm{Y}_{\mathrm{n}}\right)$ having as important parameter the correlation coefficient given in equation (12) below:

$$
r=\frac{\sum_{i=1}^{n}\left(X_{i}-\bar{X}\right)\left(Y_{i}-\bar{Y}\right)}{\sqrt{\sum_{i=1}^{n}\left(X_{i}-\bar{X}\right)^{2} \sum_{i=1}^{n}\left(Y_{i}-\bar{Y}\right)^{2}}}
$$

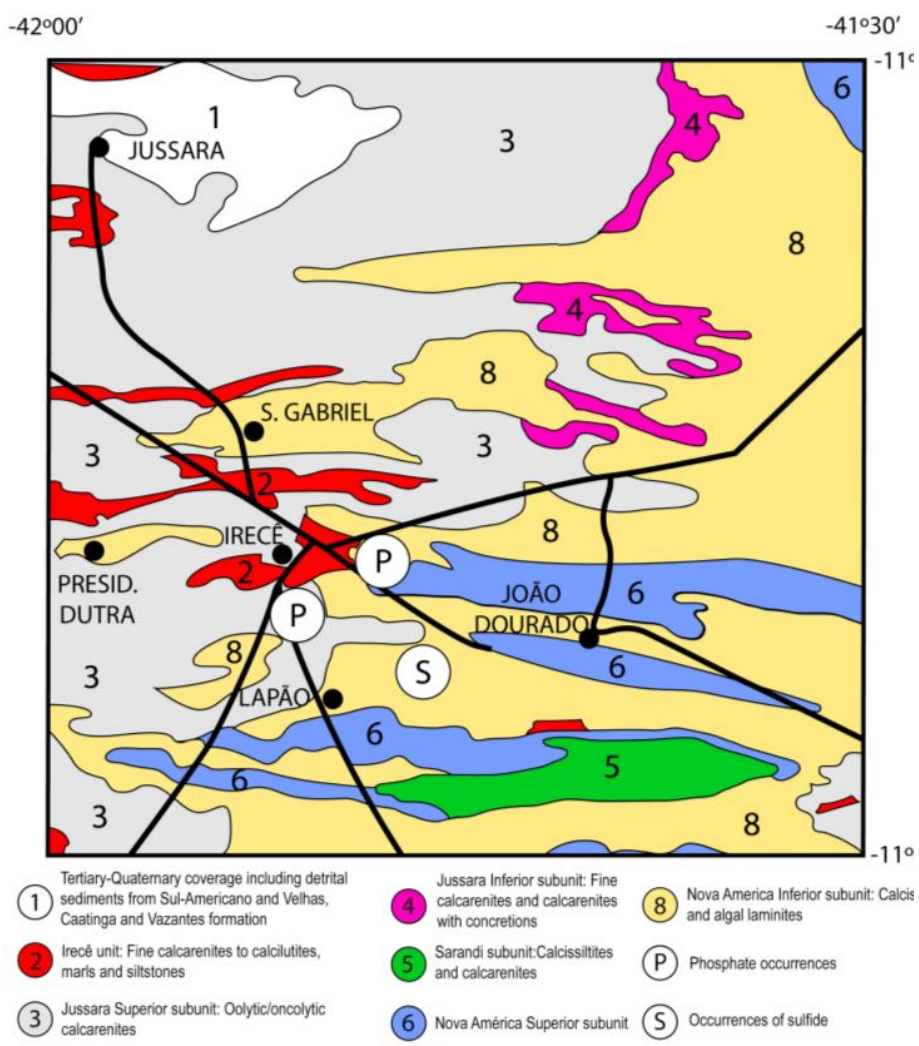

Fig. 3. Geological map. Legend. Important units of study area (from CBPM, 1993).

\section{Results}

Fig. 4 presents the results of Landsat TM (IHS Intensity, Hue and Saturation) map superimposed on Thorium (Th) in Irecê (Bahia). Fig. 4 shows the obtained results of targets 1-5 and areas A-C, previously mapped by CBPM (1993). In Fig. 4, the zones represented by pink are potential areas of phosphate mineralization. According to the results presented in this figure, the largest anomalies (represented in pink) are located in the targets 1-5.

\subsection{Airborne Survey}

\subsubsection{Uranium $\left({ }^{232} \mathrm{U}\right)$ survey}

The highest ${ }^{232} \mathrm{U}$ values are represented by the anomalies marked by red and pink colors in Fig. 5. A small anomaly, appears at the latitude $-11^{\circ} 31^{\prime}$ and longitudes from $-41^{\circ} 82^{\prime}$ to $-41^{\circ} 86^{\prime}$, located at Fazenda Juazeiro, with counts of up to 11 cps. Another important anomaly is located just above Fazenda Três Marias (coordinates: latitude $-11^{\circ} 37^{\prime}$ and longitudes from $-41^{\circ} 80^{\prime}$ to $-41^{\circ} 82^{\prime}$ ), approximately $12 \mathrm{cps}$ and in the right corner of the map bottom at latitude $-11^{\circ} 40^{\prime}$ and longitudes from $-41^{\circ} 78^{\prime}$ to $-41^{\circ} 80^{\prime}$.

\subsubsection{Thorium (232Th) survey}

In the ${ }^{232} \mathrm{Th}$ map (Fig. 6), the anomaly (red and pink colors) recorded at the latitude $-11^{\circ} 35^{\prime}$ and longitude $-41^{\circ}$ 83' located at Fazenda Juazeiro, corresponds to phosphate mineralization bands mapped by CBPM (1993), with counts $>16$ cps. Another important anomaly lies in the same position of the uranium anomaly (coordinates: latitude $-11^{\circ}$ $38^{\prime}$ and longitude $-41^{\circ} 80^{\prime}$ ) with counts at up to $18 \mathrm{cps}$ of eTh (Fig. 6).

\subsubsection{Potassium (40K) survey}

Important ${ }^{40} \mathrm{~K}$ anomalies are located at Fazenda Juazeiro and extend from the latitude- $11^{\circ} 31^{\prime}$ to $-11^{\circ} 33^{\prime}$ and from the longitude $-41^{\circ} 82^{\prime}$ to $-41^{\circ} 84^{\prime}$, with counts $>24$ cps (Fig. 7). The anomaly located at Fazenda Três Marias (Fig. 7) is situated at the latitude $-11^{\circ} 38^{\prime}$ and longitude $-41^{\circ} 81^{\prime}$, with counts $>24 \mathrm{cps}$. In general, the pattern of ${ }^{40} \mathrm{~K}$ anomalies has a marked tendency in the N-S direction, where this distribution is perpendicular to the longitude $-41^{\circ} 82^{\prime}$.

\subsection{Ground Survey}

\subsubsection{Uranium $(232 \mathrm{U})$ at Ground survey}

In the ${ }^{232} \mathrm{U}$ map (Fig. 8), two anomalous peaks were observed (coordinates: latitude $-11^{\circ} 33^{\prime}$ and longitude $-41^{\circ}$ $\left.81^{\prime}\right)$, associated to cambisols in a large slab of limestone occurrence. The extension of this anomaly to the west reaches the Fazenda Juazeiro, mapped as a phosphorus-rich target. 


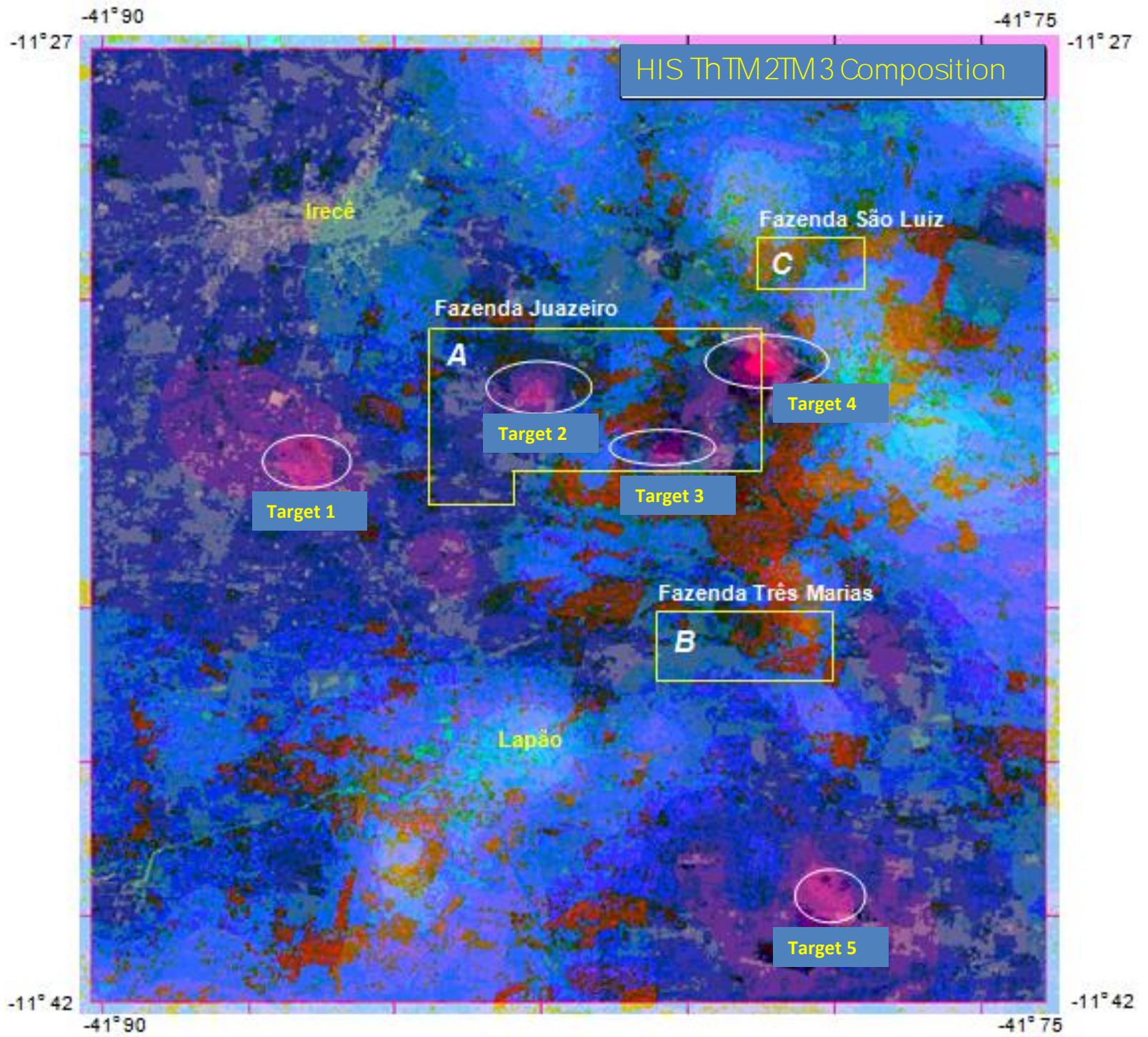

Fig. 4. Landsat TM (IHS) map superimposed on thorium (Th), in Irecê (Bahia).

The measured points at Fazenda São Luiz are associated with the occurrence of cambisols and vertisols, with small blocks of rolled limestone and some concretions of manganese. The geomorphological environment is characterized by the presence of dolines rich in organic soils. There is a second strip, slightly outside the mineralized area (coordinates: latitudes from $-11^{\circ} 38^{\prime}$ to $-11^{\circ} 40^{\prime}$ and longitudes from $-41^{\circ} 78^{\prime}$ to $-41^{\circ} 83^{\prime}$; Fig. 8 ).

\subsubsection{Thorium (232 Th) at Ground survey}

Important anomalies for ${ }^{232} \mathrm{Th}$ were found in the latitude $-11^{\circ} 33^{\prime}$ and longitude $-41^{\circ} 81^{\prime}$ corresponding to Fazenda Juazeiro and Fazenda Rufino, where an important phosphate anomaly was located (Fig. 9). At the Fazenda Três Marias, latitude $11^{\circ} 36^{\prime}$ and longitude $-41^{\circ} 84^{\prime}$ (Fig. 9), a ${ }^{232} \mathrm{Th}$ anomaly is observed in a zone of cambisol, associated with thick slabs of limestone. In ${ }^{232} \mathrm{Th}$ map (Fig. 9), an important anomaly (latitude $-11^{\circ} 40^{\prime}$ and longitude from $-41^{\circ} 80^{\prime}$ to $41^{\circ} 82^{\prime}$ ) outside the targets mapped by CBPM (1993) can be observed. The configuration of the anomalies observed in the ${ }^{232} \mathrm{Th}$ maps (Figs. 4, 6-9) are outlined in the E-W direction.

\subsubsection{Potassium $\left({ }^{40} \mathrm{~K}\right)$ at Ground survey}

At south of the Fazenda Três Marias, a ${ }^{40} \mathrm{~K}$ anomaly (Fig. 10) occurs in a zone with cambisols rich in ferruginous nodules and concretions. An important anomaly of ${ }^{40} \mathrm{~K}$ in 
the area of Fazenda Juazeiro is also observed, at the latitude $-11^{\circ} 33^{\prime}$ and longitude $-41^{\circ} 84^{\prime}$, with NW-SE predominat direction.

\subsection{Trend correlation coefficient}

The strength of the linear association between two variables quantified by the correlation coefficient is presented in Table 2.

According to Table 2 the highest correlation is observed between ${ }^{232} \mathrm{Th}$ and ${ }^{40} \mathrm{~K}(\mathrm{r}=0.9262)$ for ground gamma ray measurements. According to Table 2, ${ }^{232} \mathrm{U}$ and ${ }^{232} \mathrm{Th}$ correlations for ground data are higher than for the airborne data. This difference is also observed when ${ }^{232} \mathrm{U}$ and ${ }^{40} \mathrm{~K}$ distribution data are compared; it is higher the correlation for ground data $(r=0.4407)$ than for airborne data $(\mathrm{r}=0.0636)$, as well as for ${ }^{232} \mathrm{Th}$ and ${ }^{40} \mathrm{~K}$ (ground data with $r=0.9262$ and airborne data with $r=0.2690)$. These differences in correlations are caused by the distance between the measurement lines be larger in airborne surveys compared to that of ground surveys.

Tab. 2. Correlations at the two measurement levels.

\begin{tabular}{|l|c|c|}
\hline $\begin{array}{c}\text { Isotopic } \\
\text { values }\end{array}$ & $\begin{array}{c}\text { Ground } \\
\text { Measurements }\end{array}$ & $\begin{array}{c}\text { Airborne } \\
\text { Data }\end{array}$ \\
\hline${ }^{232} \mathrm{U}$ and ${ }^{232} \mathrm{Th}$ & 0.3174 & 0.0398 \\
\hline${ }^{232} \mathrm{U}$ and ${ }^{40} \mathrm{~K}$ & 0.4407 & 0.0636 \\
\hline${ }^{232} \mathrm{Th}$ and ${ }^{40} \mathrm{~K}$ & $\mathbf{0 . 9 2 6 2}$ & 0.2690 \\
\hline
\end{tabular}

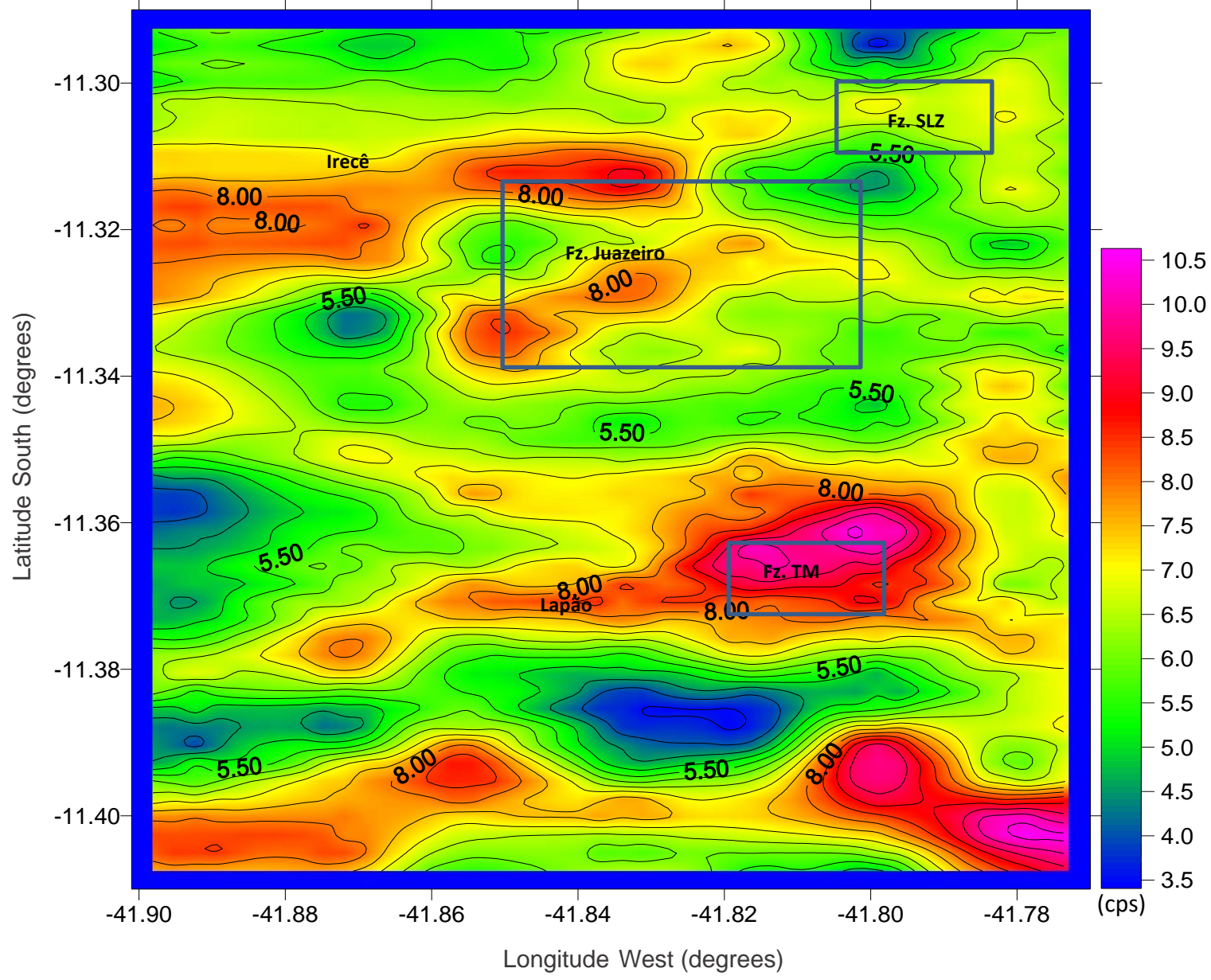

Fig. 5. Uranium (232U) map (cps), airbone geophysics in Irecê (Bahia). Legend: Fz. Juazeiro - Fazenda Juazeiro; Fz. SLZ - Fazenda São Luís; Fz. TM - Fazenda Três Marias. 


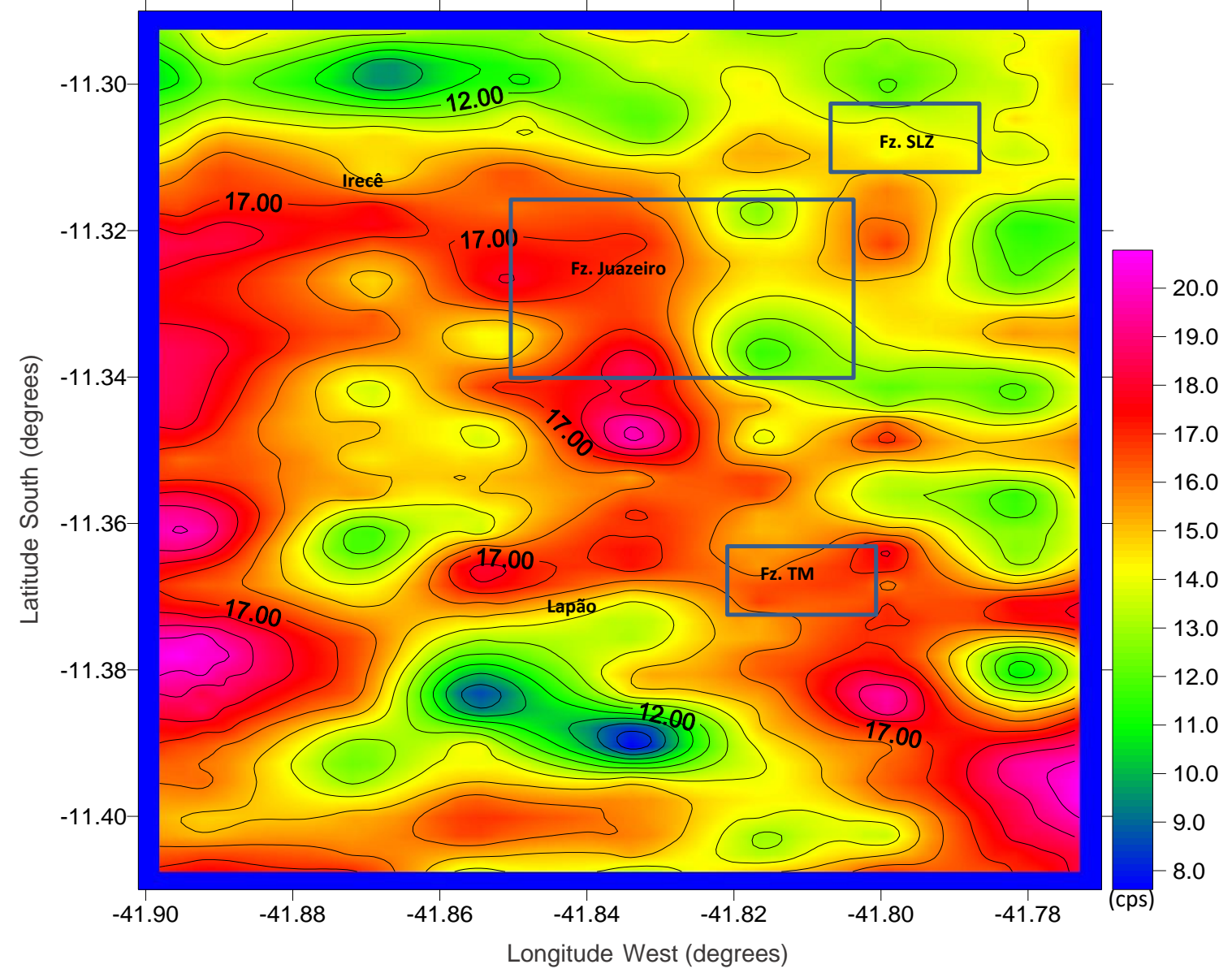

Fig. 6. Thorium (232Th) map (cps), airbone geophysics in Irecê (Bahia). Legend: Fz. Juazeiro - Fazenda Juazeiro; Fz. SLZ - Fazenda São Luís; Fz. TM - Fazenda Três Marias

\section{Discussion}

The combined classes in HIS (Hue, Intensity and Saturation) composition show that the Th and TM2 and TM3 Landsat bands in the region are covered in most areas by limestone rocks. These rocks are associated with phosphates in the Irecê region, according to the CBPM (1993). These mineralizations on apatite occurrences corroborates the results of previous researches such as that of Ferreira et al. (1992). The airborne gamma ray contour maps (Figs. 5-7) show a pattern of anomalies with an eastwest tendency following the arrangement of the main structures (faults and folds). Similar remarks were also obtained by the geological studies carried out by CBPM (1993).

The results revealed by airborne gamma ray contour maps (Fig. 5 and 7) are similar to those shown by ground geophysics contour maps (Figs. 8 and 10) for each isotope respectively. In this discussion, it is assumed that the general patterns obtained for each element through airborne and ground geophysics are similar. However, there is small differences in the arrangement of the anomalies in the ground geophysics contour maps (Figs. 8 and 10) in relation to the airborne geophysics contour maps (Figs. 5 and 7) due to a number of reasons, which mainly include differences in radius of the coverage area between the airborne and ground surveys considering the scale of the observed concentrations heterogeneities.

The results of the airborne survey for ${ }^{232} \mathrm{U}$ show that the anomalies of this element have a low relation with the phosphate mineralization (Figs. 5 and 8). As described by Misi and Kyle (1994), the Irecê sedimentary basin is characterized in tectonic terms by small fractures with folding systems whose axes lie in the E-W direction. Thus, there is a tendency of uranium as an element of easy leaching, following a distribution according to the processes that affected the lithology, especially at the surface level. The dolines may constitute a compartment in the landscape, favoring a greater mobilization of uranium in relation to thorium and potassium. 


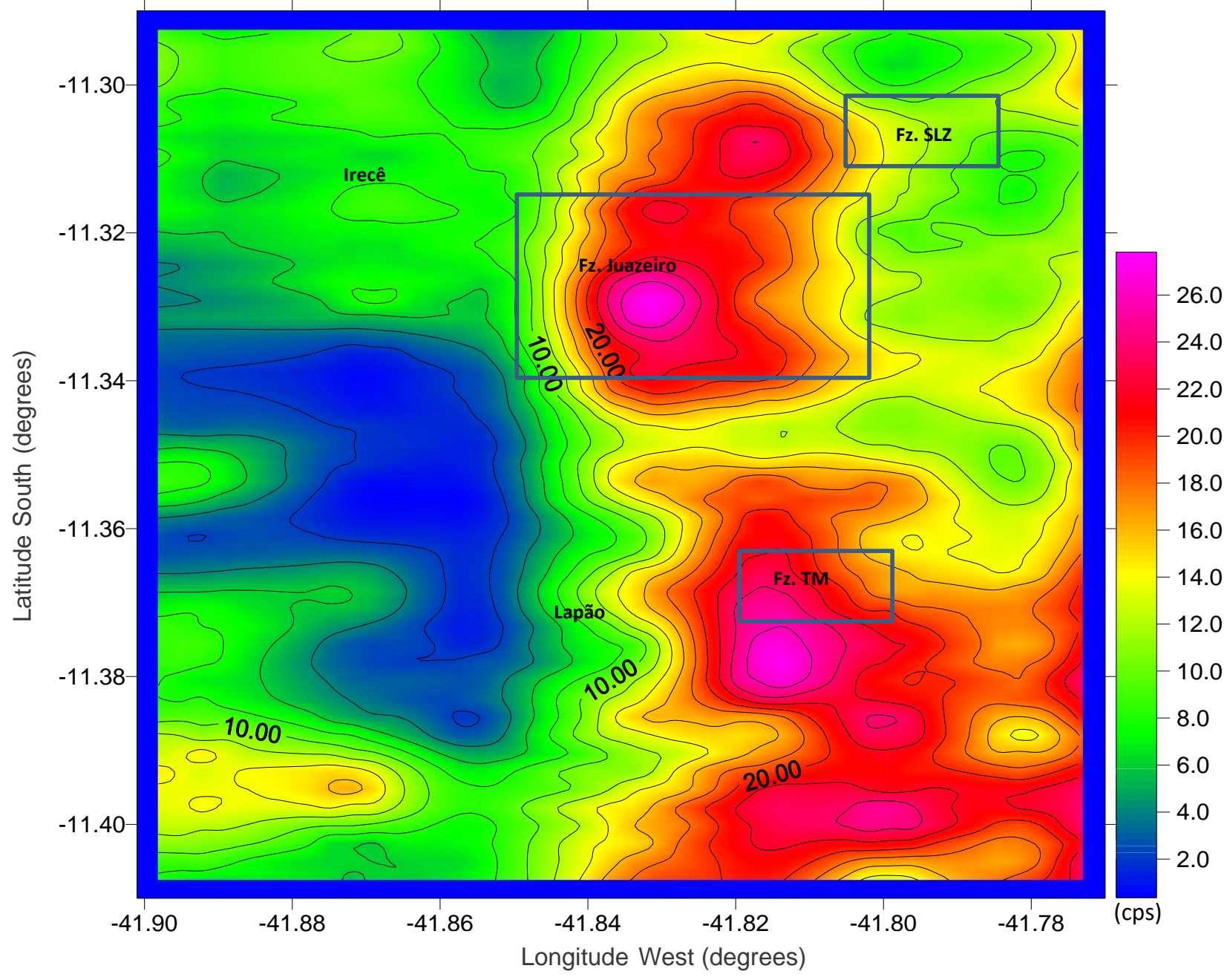

Fig. 7. Potassium $\left({ }^{40} \mathrm{~K}\right)$ map (cps), airbone geophysics in Irecê (Bahia). Legend: Fz. Juazeiro - Fazenda Juazeiro; Fz. SLZ - Fazenda São Luís; Fz. TM - Fazenda Três Marias.

Potassium $\left({ }^{40} \mathrm{~K}\right)$ anomalies, with an N-S tendency, do not present a direct and clear relationship with the phosphate mineralization areas identified by CBPM (1993) in the Irecê region. This aspect may be due to the geomorphology of the area that is complex and to the heterogeneity of the mineralogical composition of the surface rocks which may justify the low isotopic values of ${ }^{40} \mathrm{~K}$ in the areas of phosphate mineralization.

Uranium can be associated with apatite (Rehtijarvi et al., 1979; Fuller et al., 2002). However, the ${ }^{238} \mathrm{U}$ map shows that the anomalies of this isotope are not coincident with the mineralization areas identified by CBPM (1993). According to Ferrari (1994), the Earth Rare Elements concentrations are impoverished in the study area. Therefore, we can suppose that uranium should have been substituted in the crystalline structure of the apatite by other elements.

This replacement should be the cause of the impoverishment of this element at the surface level of Irecê region. Usually, uranium is more leachable than thorium and potassium (Fuller et al., 2002; Scientific, Technical, Environmental, Human Health and Safety, and Regulatory Aspects of Uranium Mining and Processing in Virginia, 2012). The results of the present work evidence that ${ }^{238} \mathrm{U}$ anomaly follows the land relief, with relatively high concentrations in dolines where the organic matter content increase. The ${ }^{232} \mathrm{Th}$ map also shows anomalies (Figs. 6, 9) associated with very high mineralization in the targets 2,3 and 4 (Fig. 4 of the Landsat TM Images) which were 
previously mapped by CBPM (1993). The results obtained in this work allowed to identify two other important anomalies of ${ }^{232} \mathrm{Th}$ associated with phosphate mineralization, target 1 and 5. The map in Fig. 4 also reveals that in Fazenda Três Marias and Fazenda São Luis (farms), previously considered to be potential areas of phosphate mineralization, have in fact poor mineralization. The geophysical results analyzed in this work reveal strong evidence of the occurrence of phosphates in Fazenda Juazeiro (targets 2, 3 and 4) agreeing with the previous studies carried out by CBPM (1993). The results obtained in target 1 and 5 indicate that these areas also have potential for phosphate mineralization, what was previously unknown. However, there may be other sites with mineralization potential (marked with pink in Fig. 4), but they did not reveal the correspondence to the radioactive elements maps.

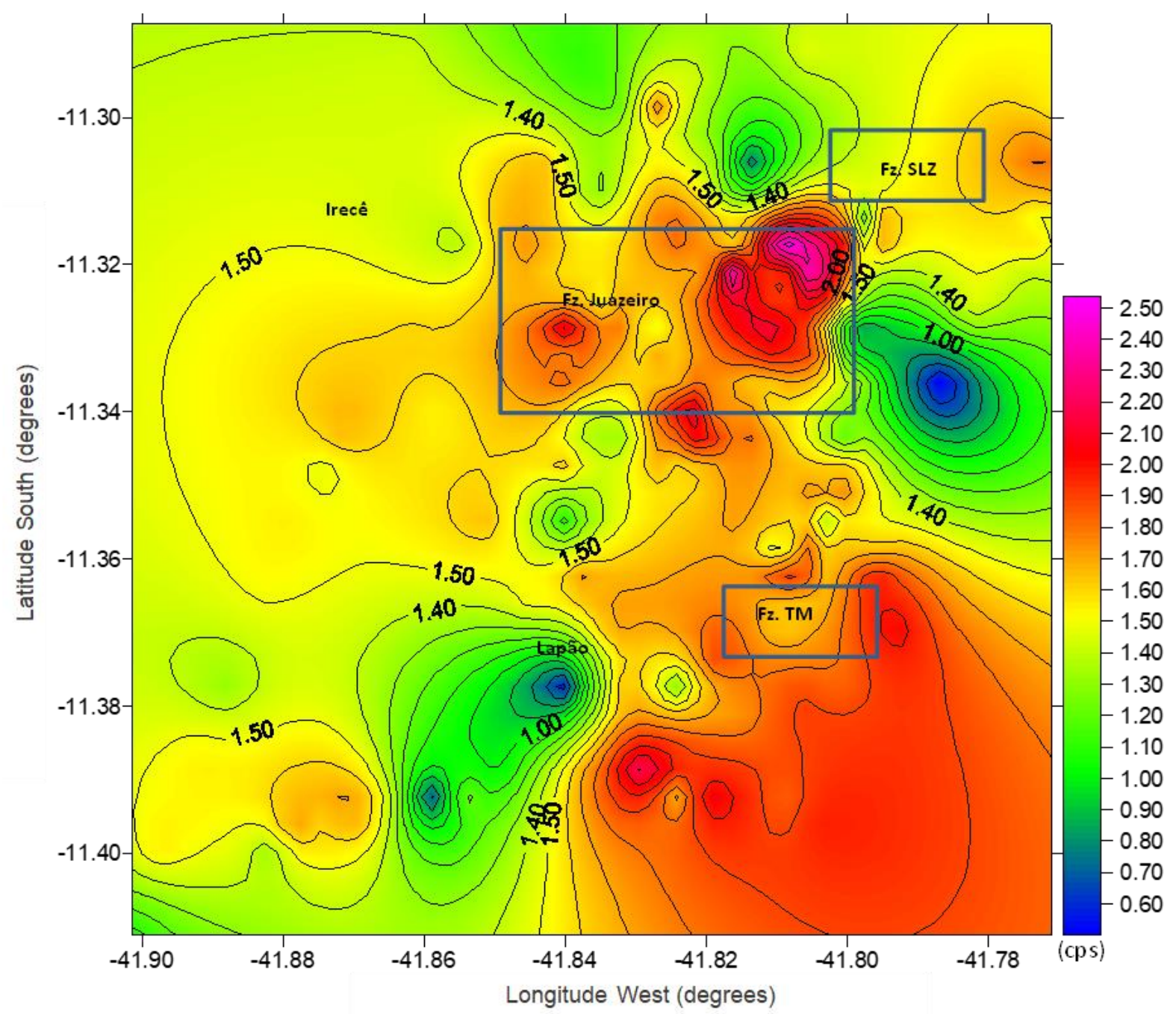

Fig. 8. Uranium ( $\left.{ }^{232} \mathrm{U}\right)$ map (cps), ground geophysics in Irecê area (Bahia). Legend: Fz. Juazeiro - Fazenda Juazeiro; Fz. SLZ - Fazenda São Luís; Fz. TM - Fazenda Três Marias. 


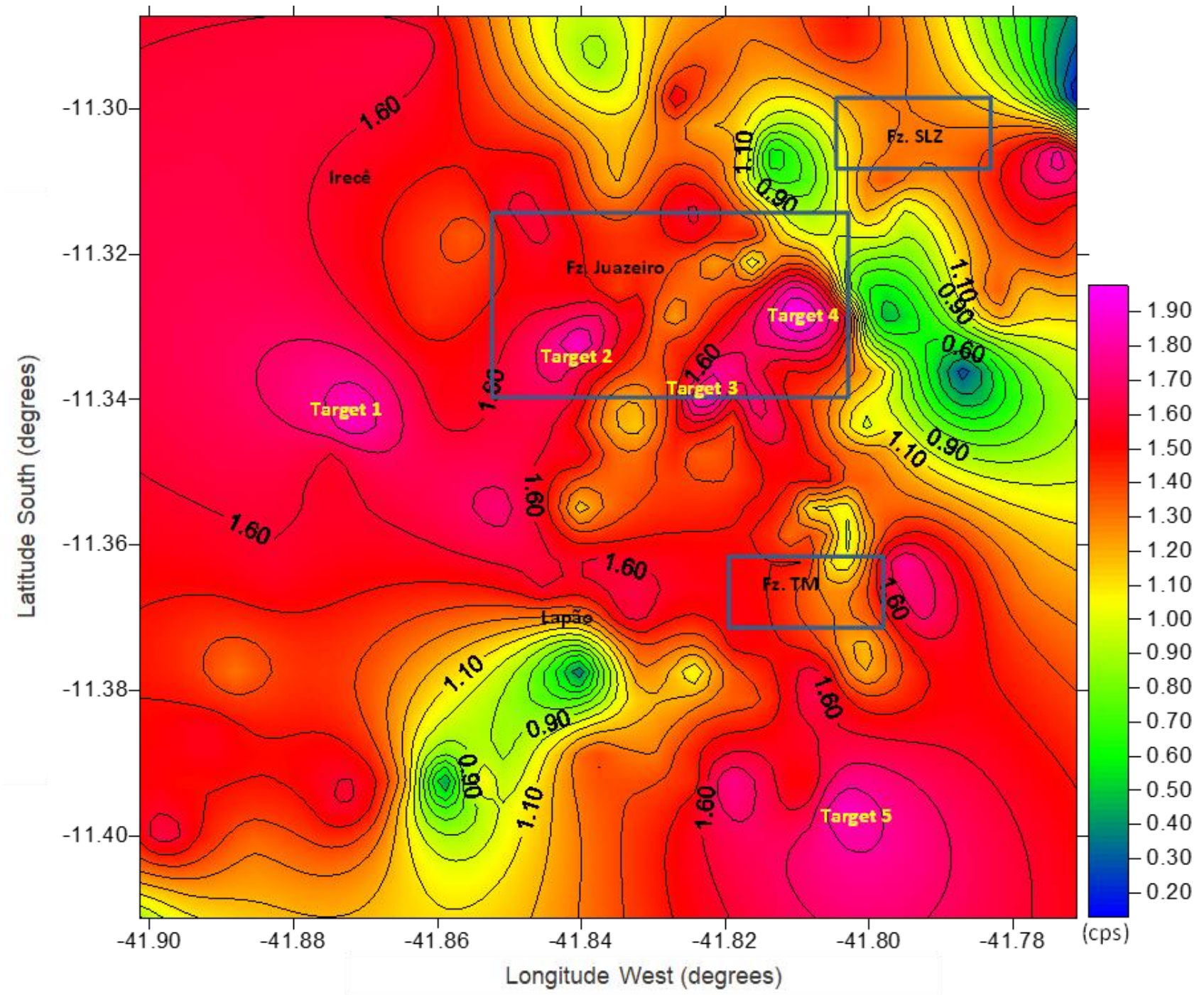

Fig. 9. Thorium (232Th) map (cps), ground geophysics in Irecê area (Bahia). Legend: Fz. Juazeiro - Fazenda Juazeiro; Fz. SLZ - Fazenda São Luís; Fz. TM - Fazenda Três Marias.

The satellite image (Fig. 4) allows inferring two different situations in the scope of the superficial distribution of Th and $\mathrm{U}$ isotopes. While $\mathrm{U}$ can be leached from weathering of stromatolites and phosphate rocks (bee house and gravel), Th remains in the phosphate-rich carbonate rocks (Ferrari, 1994).

Measurements in the areas rich in stromatolites showed in general, for soils, higher isotopic values of ${ }^{232} \mathrm{Th}$ and small ones for ${ }^{232} \mathrm{U}$ (Wellman et al., 2008). However, as part of the apatite appears in the soil constitution, whether in the cuttings or in its clay matrix, it still holds a signature of the radioactive elements, allowing using these elements as tracers for phosphate mineralization.
In the Irecê region, ${ }^{232} \mathrm{Th}$ presents in some locals major anomalies in cambisols soil type. According to Ferreira et al. (1992) clay eutrophic cambisols predominate in the region. According to Embrapa (1973), the cambisol is a little thick and underdeveloped soil, with an incipient B-horizon, which is often crusty. These soils have very low permeability due to the high content of silt (Embrapa, 1973). The low permeability of the cambisols makes Th a non-leachable element. Its presence in this kind of soil may be due to little mobilization in the area. Despite the ${ }^{40} \mathrm{~K}$ and ${ }^{232} \mathrm{Th}$ present high positive correlation $(r=0.9262)$ in ground gamma ray measurements, the results of potassium are not related to the mineralizations identified by CBPM (1993). 
Therefore, even though it is not so mobile like uranium, ${ }^{40} \mathrm{~K}$ does not serve as an element of comparison. The maps of ${ }^{232} \mathrm{Th}$ (Figs. 6 and 9) evidence anomalies related to the geological mapping of surficial phosphates mineralization. Which means that ${ }^{232} \mathrm{Th}$ anomalies are indicative of phosphate mineralization and are useful data for phosphate mapping in the region of Irecê.

\section{Conclusion}

Uranium $\left({ }^{232} \mathrm{U}\right)$ and ${ }^{40} \mathrm{~K}$ anomalies recorded by airborne survey and ground survey did not show a good correlation with phosphate mineralization. In contrast, the surface data showed that the ${ }^{232} \mathrm{Th}$ anomalies present an increasing trend in the phosphate-mineralized region. Therefore, this element can be used to define and prospect mineralized areas in phosphate.

There is a good relation between ${ }^{232} \mathrm{Th}$ radioactive data and mineralized areas identified by CBPM. However, the results of this work suggest that the area with mineral potential is larger than that was initially recognized the CBPM. Satellites images band can be combined with radioactivity gamma ray maps to understand the mobility and the concentration of surficial phosphates and the geometry of important areas for prospecting.

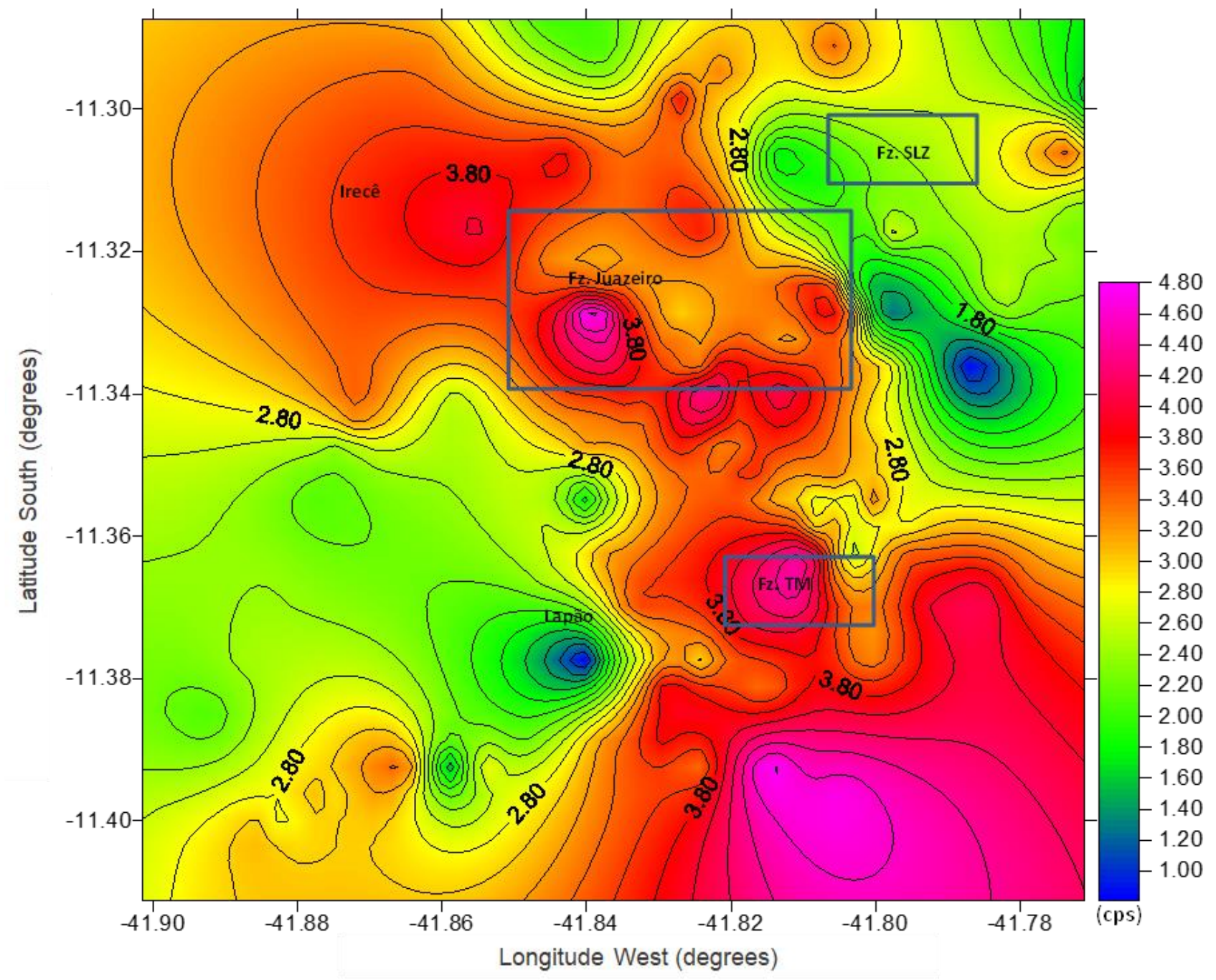

Fig. 10. Potassium $\left({ }^{40} \mathrm{~K}\right)$ map (cps), ground geophysics in Irecê area (Bahia). Legend: Fz. Juazeiro - Fazenda Juazeiro; Fz. SLZ - Fazenda São Luís; Fz. TM - Fazenda Três Marias. 


\section{Acknowledgment}

The authors would like to thank Fundação de Amparo à Pesquisa do Estado de São Paulo- FAPESP (Foundation for Research Support of the State of São Paulo) for the financial support for this research and the fieldwork and Instituto de Astronomia, Geofísica e Ciências Atmosféricas - IAG (Institute of Astronomy, Geophysics and Atmospheric Sciences). The authors are very grateful to Professor Joaquim Júlio de Oliveira, of Universidade Federal da Bahia, Salvador, for the given support during the fieldwork.

\section{References}

Alkmim, F.F., 2004. O que faz de um cráton um cráton? O Cráton do São Francisco e as revelações almeidianas ao delimitá-lo. In: Mantesso-Neto V., Bartorelli A., Carneiro C. D. R, Brito-Neves B. B. (org.) Geologia do Continente Sul Americano: Evolução da obra de Fernando Flávio Marques de Almeida. Beca, p.1735.

Bomfim, L.F.C., Rocha, A.J.D., Pedreira, A.J., Morais Filho, J.C. de, Guimarães, J.T., Tesch, N.A., 1985. Projeto Bacia de Irecê - Relatório Final, Salvador, CPRM - Companhia de Pesquisa de Recursos Minerais, 3v. Contrato SME/CPM/CPRM.

CBPM (Companhia Baiana de Pesquisa Mineral), 1993. Estratigrafia, sedimentologia e recursos minerais da Formação Salitre na Bacia de Irecê. Por Sousa, S. L.; Série arquivos abertos 2.

CPRM (Companhia de Pesquisa de Recursos Minerais), PROSPEC. DNPM, 1974. Projetos Bahia, Bahia II, Sul da Bahia, Leste do Tocantins/Oeste do Rio São Francisco. Relatório da reunião, Salvador, set./out. 1974. Salvador: s.n., 1974. 17p.

Dalton de Souza, J., Kosin M., Melo R.C., Santos R. A., Teixeira L. R., Sampaio A. R., Guimarães J. T., Vieira Bento R., Borges V. P., Martins A. A. M., Arcanjo J. B., Loureiro H. S. C., Angelim L. A. A. 2003. Mapa geológico do Estado da Bahia - Escala 1:1.000.000. Salvador: CPRM, Versão 1.1. Programas Carta Geológica do Brasil ao Milionésimo e Levantamentos Geológicos Básicos do Brasil (PLGB). Convênio de Cooperação e Apoio Técnico-Científico CBPM/CPRM.

De Meijer, R.J., Stapel C., Jones, D.G., Roberts, P.D., Rozendaal, A., Macdonald, W.G., 1997. Improved and New Uses of Natural Radioactivity in Mineral Exploration and Processing. Exploration and Mining Geology, 6(1), 105 - 117.

Dickson, B.L., Scott, K.M., 1997. Interpretation of aerial gammaray surveys adding the geochemical factors. AGSO Journal of Australian Geology and Geophysics, 17(2), 187-200.

Eisenbud, M., Thomas, G., 1997. Environmental Radioactivity: From Natural, Industrial, and Military Sources, 4th Edition (Academic Press, San Diego).

Embrapa, 1973. Mapa Exploratório de Reconhecimento de Solos. Salvador, Secretaria de Agricultura/Ba.

Ferrari, V.C., 1994. Estudo mineralógico e geoquímico dos minérios fosfatados de Irecê-Bahia. Dissertação de Mestrado. Programa de Pós-Graduação em Geoquímica e Geotectônica. Instituto de Geociências - USP.
Ferreira, C., Moreira-Nordemann, L.M., Nordemann, D.J.R., 1992. A Radioatividade Natural da Região de Irecê, Ba. Revista Brasileira de Geociências, 22(2), 167-174.

Fuller, C.C., Bargar, J.R., Davis, J.A., Piana, M.J., 2002. Mechanisms of Uranium Interactions with Hydroxyapatite: Implication for Groundwater Remediation. Environmental Science and Technology, 36,158-165.

Kuchenbecker, M., Reis, H.L.S., Fragoso, D.G.C., 2011. Caracterização estrutural e considerações sobre a evolução tectônica da Formação Salitre na porção central da Bacia de Irecê, norte do Cráton do São Francisco (BA). Geonomos, 19(2), 42-49. www.igc.ufmg.br/geonomos

Leipunskii, O.I., Novozhilov, B.V., Sakharov, V.N., 1965. The propagation of gamma quanta in matter. Translated by Prasenjit Basu. Pergamon Press. Oxford, London.

Lillesand, T.M. Kiefer, R.W., Chipman, J.W., 2008. Remote sensing and image interpretation. John Wiley and Sons Inc., New York, $6^{\mathrm{a}} \mathrm{Ed}$.

Mascarenhas, J.F., Pedreira, A.J., Misi, A., Motta, A.C., SÁ, J.H.S., 1984. Província São Francisco. In: Almeida, F. F.; Hasui, Y. (editores). O Pré-cambriano do Brasil. São Paulo: Edgard Blücher, p. 46-122.

McInnis, T.R., Akhavi, M.S., 1986. Integration of radiometric and Landsat digital data for geologic investigation and exploration, Guysboroug area, Nova Scotia. In: Canadian Symposium on Remote Sensing, 10, Edmonton, AB, May 5-8. Proceedings. Edmonton, AB, M. Diane Thompson and Ronald J. Brown, v. $1, \mathrm{p} 11-17$.

Meyer, P.L., 1984. Probabilidade - Aplicações a Estatística. L.T.C. - Livros Técnicos e Científicos S. A. 2a Edição - Rio de Janeiro.

Minty, B.R.S., 1988. A review of airborne gamma-ray spectrometric data processing techniques. Department of primary industries and energy bureau of mineral resources, Geology and Geophysics. Report Nr. 255 - Division of Geophysics. Australian government publishing services Canberra.

Misi, A., Kyle, J.R., 1994. Upper Proterozoic carbonate stratigraphy, diagenesis, and stromatolitic phosphorite formation, Irece Basin, Bahia, Brazil. Journal of Sedimentary Research A: Sedimentary Petrology \& Processes, 64 A(2), 299310.

Misi, A., 1979. O Grupo Bambuí no Estado da Bahia. In: Inda, H. V., organizado pela Geologia e Recursos Minerais do Estado da Bahia. Textos Básicos. Salvador, SME/CPRM, Vol. 1, p. 119154.

Monteiro, M.D., 1990. Projeto Irecê-Lapão, $3^{\text {a }}$ Etapa Reprogramação. Relatório não publicado, convênio SME/CBPM, Salvador, Janeiro 1990, 2 vol.

Monteiro, M.D., 1989. Projeto Irecê-Lapão, $2^{\mathrm{a}}$ Etapa Reprogramação. Relatório não publicado, convênio SEM/CBPM, Salvador, Agosto 1989, 2 vol.

Monteiro, M.D., 1988. Projeto Irecê-Lapão, 1a Etapa Reprogramação. Relatório não publicado, convênio SME/CBPM, Salvador, 2 vol.

Neves, J.P., 1985. Projeto Bacia de Irecê. Salvador, Companhia de Pesquisa de Recursos Minerais. Convênio SME-CPRM. 
Parks, E.J., 2015. The Compton Effect - Compton Scattering and Gamma Ray Spectroscopy - Department of Physics and Astronomy 401 Nielsen Physics Building the University of Tennessee Knoxville, Tennessee 37996-1200.

Pecora, W.T., 1967. A summary of salient features of the geology of phosphate deposits, their origin, and distribution. Geological Survey Bulletin 1252-d. United States Government Printing Office, Washington.

Reginer, P., Lasaga, A.C., Berner, R.A., 1994. Mechanism of $\mathrm{CO}_{3}^{2-}$ substitution in carbonate-fluorapatite: Evidence from FTIR spectroscopy, ${ }^{13} \mathrm{C}$ NMR and quantum mechanical calculations. American Mineralogist, 79, 809-818.

Rehtijarvi, P., Aikas, O., Makela, M., 1979. A middle Precambrian uranium and apatite-bearing horizon associated with the Vihanti zinc ore deposit, western Finland. Economic Geology 74 (5). DOI: 10.2113/gsecongeo.74.5.1102

Sahu, S.K., Ajmal, P.Y., Bhangare, R.C., Tiwari, M., Pandit, G., 2014. Natural radioactivity assessment of a phosphate fertilizer plant area. Journal of Radiation Research and Applied Sciences 7 (1), 123-128.

Scientific, Technical, Environmental, Human Health and Safety, and Regulatory Aspects of Uranium Mining and Processing in
Virginia, 2012. Uranium Mining in Virginia. National Academy of Sciences. Bookshelf.

Shalaby, M.H., Bishta, A.Z., Roz, M.E., 2010. Integration of Geologic and Remote Sensing Studies for the Discovery of Uranium Mineralization in Some Granite Plutons, Eastern Desert, Egypt. Journal of King Abdul-Aziz University: Earth Sciences 21 (1), 1-25.

Srivastava, N.K., 1986. Algumas observações sobre os estromatólitos do Grupo Una (Bahia) e Vaza Barris (Sergipe), nordeste do Brasil. Ciências da Terra (3), 7-11.

UNSCEAR 2000 Report, Vol. I. Sources And Effects Of Ionizing Radiation. United Nations Scientific Committee on the Effects of Atomic Radiation. Availabel at http://www.unscear.org/unscear/en/publications/2000_1.ht $\mathrm{ml}$ (acessed at October 2017)

Wellman, D.M., Fruchter, J.S., Vermeul, V.R., Williams, M.D., 2008. Challenges associated with apatite remediation of Uranium in the 300 area aquifer. Prepared for the U.S. Department of Energy under Contract DE-AC05-76RL01830. Pacific Northwest National Laboratory Richland, Washington 99352 